\title{
Factors influencing jaundice in immigrant Greek infants
}

\author{
J. H. DREW, JEAN BARRIE, I. HORACEK, AND W. H. KITCHEN
}

From the Departments of Paediatrics, and Obstetrics and Gynaecology, University of Melbourne, and the Royal Women's Hospital, Melbourne, Australia

SUMmARY A study of 887 consecutively born immigrant Greek and 220 Anglo-Saxon Australian infants has shown that serum bilirubin concentrations are influenced by these factors: breast feeding, delivery with forceps, gestation, birthweight, sex of the infant, presence of hypoxia, presence of blood group incompatibility, a positive direct Coombs's test, maternal sepsis, and administration to the mother of promethazine hydrochloride, reserpine, chloral hydrate, barbiturates, narcotic agents, diazepam, oxytocin, aspirin, and phenytoin sodium. Apart from the administration of promethazine hydrochloride, reserpine, chloral hydrate, and quinalbarbitone sodium, only two factors, breast feeding and delivery by forceps, occurred with different frequencies in the immigrant Greek and the Australian infants. Among the Greek infants with jaundice, there were few where the cause of the jaundice was inapparent. The immigrant Greek and Australian newborn populations were therefore remarkably similar. Since differences of frequency and severity of jaundice do exist in infants born in Greece, this difference must be lost when the parents emigrate, and therefore an environmental factor must be incriminated as the causative agent for jaundice of unknown origin in Greece.

Jaundice has been shown to be exceptionally frequent and severe in infants born in: Greece (Doxiadis et al., 1961). Glucose-6-phosphate dehydrogenase (G-6PD) deficiency has explained only some of the cases of jaundice (Fessas et al., 1962). Because of the accumulation of cases of severe jaundice in certain families (Fessas et al., 1962) and in certain areas of Greece (Valaes et al., 1969) it has been assumed that the unknown contributing factor in the remaining cases was intrinsic and probably genetically determined. The findings in immigrant Greek infants born in Australia of no increased incidence or severity of jaundice when compared to Australian infants (Drew and Kitchen, 1976a), of no effect of parental birthplace within Greece on serum bilirubin concentrations (Drew and Kitchen, 1976b), and of G-6-PD deficiency having a less than expected effect on severe jaundice (Drew et al., 1977), led us to study the factors which influence jaundice in Australian and immigrant Greek newborn infants.

\section{Methods}

Serum bilirubin was measured at 48 and 72 hours of age in a consecutive series of 930 infants born to Received 18 April 1977 mothers who had recently emigrated from Greece and in 232 randomly selected Anglo-Saxon Australian infants for comparison. Additional serum bilirubin measurements were obtained after 72 hours of age if clinically warranted. 55 infants (43 Greek and 12 Australian) were excluded because of incomplete data. Standardised investigations of maternal and cord blood were performed.

Maternal blood investigations were ABO group, Rhesus type, antibodies against major red cell antigens, $\mathrm{Hb}$, red cell count, packed cell volume, mean corpuscular volume (MCV), and G-6-PD assay. In the Greek mothers if $\mathrm{Hb}$ was $<10 \mathrm{~g} / \mathrm{dl}$, and/or the mean corpuscular $\mathrm{Hb}$ was $<27 \mathrm{pg}$, and/or MCV was $<81 \mu^{3}$, additional investigations were made of blood film, reticulocyte count, serum iron, and $\mathrm{HbF}$ and $\mathrm{A}_{2}$.

Cord blood investigations were ABO group, Rhesus type, direct Coombs's elution of antibodies against major red cell antigens, $\mathrm{Hb}$, and G-6-PD screen. Serum bilirubin was measured in capillary blood samples by a modification of the method of Malloy and Evelyn (1937). G-6-PD screen was performed using the method of Smith and Whiteside (1975), which allows for the effect of red cell aging upon the enzyme activity by calculating the ratio of 
G-6-PD activity to the activity of a second enzyme, 6-phosphogluconate dehydrogenase.

Correlations by three separate statistical tests (Pearson, Kendall and Spearman, Nie et al., 1970) were sought between serum bilirubin concentrations and gestation, birthweight, birth order in family, sex, mode of delivery, presence of hypoxia, Apgar score at 1 minute, breast or artificial feeding, history of a sib with neonatal jaundice, presence of maternal sepsis, haematological results of the mother, serological results of mother and infant, and drugs administered to the mother in labour ward. The distribution of these parameters in the Greek and Australian infants was determined to see if a bias of any factor occurred. Infants with factors shown in the first order correlation to cause jaundice were then excluded from both the Greek and Australian populations, as were infants with G-6-PD deficiency. The remaining infants were labelled those in whom no known cause for jaundice existed. These two groups were then compared.

\section{Results}

No statistical correlation with neonatal jaundice was found for birth order, Apgar score at 1 minute, history of a jaundiced sib, delivery by caesarean section, abnormalities of maternal haematological screen, and maternal administration of chlorpromazine hydrochloride, prochlorperazine, general or local anaesthesia, sulphadimidine, penicillin, and ampicillin. The factors which influenced jaundice and the incidence of each in the Greek and Australian infants are shown in Table 1 . The only differences between the two populations were found in frequency of breast feeding, forceps delivery, and maternal administration of promethazine hydrochloride, reserpine, chloral hydrate, and quinalbarbitone sodium (Table 1). In Table 2 the two groups of infants are compared in whom the cause for the jaundice was inapparent. The only difference between the groups was in the incidence of such infants: 48 of $887(5 \%)$ Greek infants compared to 35 of $220(16 \%)$ Australian infants $(P<0 \cdot 05)$.

\section{Discussion}

Studies of infants born in Greece suggest that jaundice during the newborn period is exceptionally frequent and severe (Doxiadis et al., 1961). A study of infants born in Australia of recent Greek immigrant parents failed to show an increased incidence or severity of jaundice in those infants when compared to Australian infants (Drew and Kitchen, 1976a). We decided to study which factors influenced jaundice and found that the following affected bilirubin levels (Table 1) breast feeding, forceps delivery, gestation, birthweight, sex, blood group incompatibility, presence of hypoxia, presence of maternal sepsis, and maternal administration of promethazine hydrochloride, reserpine, chloral hydrate, barbiturates, narcotic agents, diazepam, aspirin, phenytoin sodium, and oxytocin.

Of these factors, only 6 , forceps delivery, breast feeding, and the use of promethazine hydrochloride, quinalbarbitone sodium, chloral hydrate, and reserpine, occurred with different frequencies in the Greek and Australian infants. Maternal drugs have

Table 1 Factors influencing jaundice at 48 andlor 72 hours of age and incidence of each

\begin{tabular}{|c|c|c|c|c|c|c|c|}
\hline \multirow[b]{2}{*}{ Factor } & \multicolumn{3}{|c|}{ Correlations } & \multicolumn{3}{|l|}{ Infants } & \multirow{2}{*}{$\begin{array}{l}\text { Significance } \\
\text { of different } \\
\text { incidence } \\
\left(\chi^{2}\right)\end{array}$} \\
\hline & $\begin{array}{l}\text { Pearson } \\
(r)\end{array}$ & $\begin{array}{l}\text { Kendall } \\
(\boldsymbol{r})\end{array}$ & $\begin{array}{l}\text { Spearman } \\
(r)\end{array}$ & $\begin{array}{l}\text { Total } \\
\text { no. }\end{array}$ & $\begin{array}{l}\text { Australian } \\
(n)(\%)\end{array}$ & $\begin{array}{l}\text { Greek } \\
(n)(\%)\end{array}$ & \\
\hline $\begin{array}{l}\text { Breast feeding } \\
\text { Promethazine hydrochloride } \\
\text { Reserpine } \\
\text { Forceps delivery } \\
\text { Chloral hydrate } \\
\text { Quinalbarbitone sodium } \\
\text { Decreasing gestation } \\
\text { Decreasing birthweight } \\
\text { Female infant } \\
\text { Hypoxia } \\
\text { Blood group incompatibility } \\
\text { Coombs's test positive } \\
\text { Maternal sepsis } \\
\text { Pethidine hydrochloride } \\
\text { Heroin } \\
\text { Diazepam } \\
\text { Phenobarbitone sodium } \\
\text { Oxytocin infusion } \\
\text { Aspirin } \\
\text { Phenytoin sodium }\end{array}$ & $\begin{array}{c}0.067 \ddagger \\
-0.057 \ddagger \\
-0.086 \dagger \\
-0.086 \dagger \\
-0.040 \\
-0.058 \ddagger \\
-0.132 \% \\
-0.043 \\
99 \cdot 000 \dagger \\
0.082 \dagger \\
0.062 \dagger \\
0.029 \\
0.008 \\
-0.074 \dagger \\
-0.072 \dagger \\
0.044 \\
-0.049 \\
0.059 \ddagger \\
-0.038 \\
-0.078 \dagger\end{array}$ & $\begin{array}{r}0.046 \dagger \\
-0.043 \dagger \\
-0.075 \dagger \\
-0.078 \dagger \\
-0.037 \ddagger \\
-0.052 \dagger \\
-0.154 \\
-0.041 \ddagger \\
0.103 \dagger \\
0.087 \dagger \\
0.055 \dagger \\
0.064 \dagger \\
0.046 \dagger \\
-0.048 \dagger \\
-0.069 \dagger \\
0.045 \dagger \\
-0.042 \ddagger \\
0.014 \\
-0.036 \ddagger \\
-0.072 \dagger\end{array}$ & $\begin{array}{l}0.056 \ddagger \\
-0.052 \\
-0.083 \dagger \\
-0.095 \dagger \\
-0.045 \\
-0.063 \\
-0.215 \ddagger \\
-0.060 \ddagger \\
0.125 \dagger \\
0.106 \dagger \\
0.067 \dagger \\
0.078 \dagger \\
0.056 \ddagger \\
-0.059 \ddagger \\
-0.084 \dagger \\
0.035 \\
-0.052 \\
0.017 \\
-0.043 \\
-0.074 \dagger\end{array}$ & $\begin{array}{r}643 \\
492 \\
34 \\
213 \\
168 \\
83 \\
1102 \\
1104 \\
528 \\
112 \\
235 \\
53 \\
92 \\
811 \\
160 \\
94 \\
70 \\
116 \\
171 \\
37\end{array}$ & $\begin{array}{c}60(27) \\
80(36) \\
14(6) \\
29(13) \\
22(10) \\
24(11) \\
- \\
- \\
98(45) \\
22(10) \\
47(21) \\
12(6) \\
18(8) \\
153(70) \\
29(13) \\
23(11) \\
16(7) \\
28(13) \\
27(12) \\
10(5)\end{array}$ & $\begin{array}{c}583(66) \\
412(46) \\
20(2) \\
184(21) \\
146(17) \\
59(7) \\
- \\
- \\
430(49) \\
90(10) \\
188(21) \\
41(5) \\
74(8) \\
658(74) \\
131(15) \\
71(8) \\
54(6) \\
88(10) \\
144(16) \\
27(3)\end{array}$ & $\begin{array}{l}P<0.001 \\
\mathbf{P}<0.01 \\
\mathbf{P}<0.01 \\
\mathbf{P}<0.02 \\
\mathbf{P}<0.02 \\
\mathbf{P}<0.05 \\
\mathbf{N S} \\
" \\
" \\
" \\
" \\
" \\
" \\
" \\
" \\
" \\
" \\
"\end{array}$ \\
\hline
\end{tabular}

*P<0.001; $\uparrow P<0.02 ; \ddagger P<0.05 ; N S=$ not significant. 
Table 2 Infants with no known cause of jaundice: comparisons with each other and the total populations

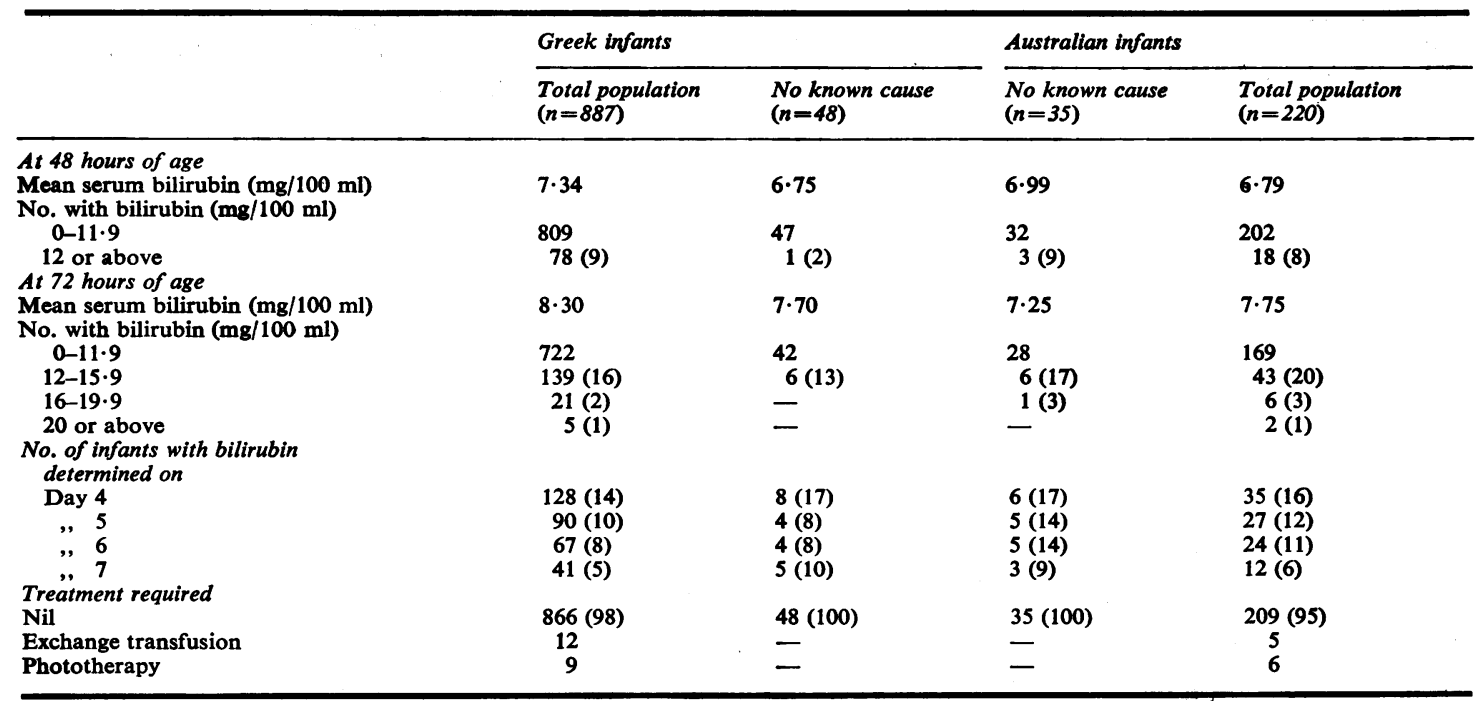

Numbers in parentheses are percentage values.

Conversion: Traditional units to SI-Bilirubin: $1 \mathrm{mg} / 100 \mathrm{ml} \approx 17 \cdot 1 \mu \mathrm{mol} / \mathrm{l}$.

been shown to alter serum bilirubin concentrations, but their effects were only marginal (Drew and Kitchen, 1976b). It is unlikely then that administration of the above four drugs would significantly bias the Greek infants. This leaves two factors. One of these (use of forceps) resulted in less jaundice and the other (breast feeding) in raised serum bilirubin levels. Delivery with the aid of forceps and breast feeding were both more common in the Greek population and these may have a selective influence on jaundice in the Greek infants. However, it must be concluded that the immigrant Greek and Australian communities were remarkably similar in factors causing jaundice.

Work in Greece has shown that the high incidence of jaundice occurred in children born in certain areas (Valaes et al., 1969) and to certain families (Fessas et al., 1962). These infants comprised a group in whom known causes of jaundice were excluded. Because of the grouping of cases the unknown agent was postulated to be intrinsic and probably genetically determined. Such a group of infants should then exist in Australia. By the finding that recent Greek immigrants fail to bring the causative agent to Australia suggested the agent was environmental (Drew and Kitchen, 1976a). To test this we determined whether a significant group of Greek infants without an obvious cause for jaundice existed in Australia. A genetic cause would indeed be most likely if this group existed. However, our study failed to show that such a group exists. In fact, fewer cases of jaundice of no apparent cause were found among the Greek than among the Australian infants. The Australian and Greek infants were remarkably similar, and since differences exist in Greek infants born in Greece, an environmental factor must be incriminated as the causative agent for jaundice of unknown origin.

\section{References}

Doxiadis, S. A., Fessas, Ph., Valaes, T., and Mastrokalos, N. (1961). Glucose-6-phosphate dehydrogenase deficiency: a new aetiological factor of severe neonatal jaundice. Lancet, 1, 297-301.

Drew, J. H., and Kitchen, W. H. (1976a). Jaundice in infants of Greek parentage: the unknown factor may be environmental. Journal of Pediatrics, 89, 248-252.

Drew, J. H., and Kitchen, W. H. (1976b). The effect of maternally administered drugs on bilirubin concentrations in the newborn infant. Journal of Pediatrics, 89, 657-661.

Drew, J. H., Smith, M. B., and Kitchen, W. H. (1977). Glucose-6-phosphate dehydrogenase deficiency in immigrant Greek infants. Journal of Pediatrics, 90, 659-660.

Fessas, Ph., Doxiadis, S. A., and Valaes, T. (1962). Neonatal jaundice in glucose-6-phosphate dehydrogenase-deficient infants. British Medical Journal, 2, 1359-1362.

Malloy, H. T., and Evelyn, K. A. (1937). The determination of bilirubin with the photoelectric colorimeter. Journal of Biological Chemistry, 119, 481-490.

Nie, N., Bent, D. H., and Hull, C. H. (1970). Statistical Package for the Social Sciences. McGraw-Hill, New York.

Smith, M. B., and Whiteside, M. G. (1975). The detection of glucose-6-phosphate dehydrogenase deficiency in Mediterraneans by comparative quantitative enzyme electrophoresis. Medical Journal of Australia, 1, 558-559. 
Valaes, T., Karaklis, A., Stravrakakis, D., Bavela-Stravrakakis, K., Petrakis, A., and Doxiadis, S. A. (1969). Incidence and mechanism of neonatal jaundice related to glucose-6phosphate dehydrogenase deficiency. Pediatric Research, $3,448-458$.
Correspondence to Dr J. H. Drew, Department of Obstetrics and Gynaecology, Mercy Maternity Hospital, Clarendon Street, East Melbourne, Victoria, 3002, Australia.

The following articles will appear in future issues of this journal:

Annotation. Drugs, infections, and congenital abnormalities. $R$. W. Smithells.

Annotation. Role of circulating soluble immune complexes in disease. R. J. Levinsky.

Aortic thrombosis in the newborn period. G. T. Knowlson and H. B. Marsden.

Computed tomography in diagnosis of abdominal masses in infancy and childhood: comparison with excretory urography. J. C. Leonidas, Barbara L. Carter, L. L. Leape, M. L. Ramenofsky, and A. M. Schwartz. Effect of children's and parents' smoking on respiratory symptoms. M. Bland, Beulah R. Bewley, Virginia Pollard, and M. H. Banks.

Tests of skeletal muscle function in children. G. P. Hosking, A. Young, V. Dubowitz, and R. H. T. Edwards. Computer system for recording and display of data from newborn infants with respiratory illness. L.P. Allen, J. S. Clifton, D. Ingram, P. N. le Souëf, E. O. R. Reynolds, and P. D. Wimberley.

Improved tube for nasojejunal feeding in low birthweight infants. D. Della Pietra, V. Gargiulo, and F. Tancredi. 